\title{
DYSPOZYCJE PRAWNE REGULUJĄCE MUZYKE I ŚPIEW LITURGICZNY PO SOBORZE WATYKAŃSKIM II (KONTEKST POLSKI)
}

Mówiąc o muzyce i śpiewie liturgicznym, napotykamy trudności w ujęciu w formę prawną tematu, dynamicznego i historycznie określonego, w którym wrażliwość artystyczna i wymogi liturgiczne często „wyprzedzały” normy prawne ${ }^{2}$. Aktualny Kodeks prawa kanonicznego nie przedstawia żadnych regulacji odnoszących się do muzyki i śpiewu. Jedynie wymieniając prawa i obowiązki wiernych świeckich, Kodeks Jana Pawła II wspomina o możliwości wykonywania przez świeckiego zadania kantora ${ }^{3}$, a także o śpiewie jako czynności wielbiącej Boga przez Kościół podczas liturgii godzin ${ }^{4}$.

Niniejszy artykuł podejmuje zagadnienie dyspozycji prawnych regulujących muzykę i śpiew liturgiczny. Ostatnie sto pięćdziesiąt lat charakteryzowało się w tym względzie dwiema wielkimi reformami - pierwsza z 1903 roku, przeprowadzona przez papieża Piusa $\mathrm{X}^{5}$ i druga $\mathrm{w}$ ramach Soboru Watykańskiego II. Głównym przedmiotem pierwszej reformy było odzyskanie „czystości” muzyki wobec licznych nadużyć, które zanieczyszczały muzykę liturgiczną. Druga reforma miała na celu aktywny i świadomy udział wiernych w zgromadzeniu liturgicznym. W niniejszym

\footnotetext{
${ }^{1}$ Ks. Robert Kantor, doktor habilitowany nauk prawnych w zakresie prawa kanonicznego. Studia na Wydziale Prawa Kanonicznego Uniwersytetu Navarry w Pampelunie. Kierownik Katedry Teologii Praktycznej i Prawa Kanonicznego na Wydziale Teologicznym Sekcja w Tarnowie Uniwersytetu Papieskiego Jana Pawła II w Krakowie. Autor wielu książek i artykułów z prawa kanonicznego i wyznaniowego.

${ }^{2}$ Por. F. Romita, Ius musicae liturgice,. Dissertatio historico iuridica, Torino 1936; S. Martin, Musica liturgica e diritto canonico. Cenni sull'evoluzione normativa, Padova 2002; N. Tanragi, Musica Sacra, w: J. Otaduy, A. Viana, J. Sedano (red.), Diccionario General De Derecho Canónico, vol. V, Pamplona 2012, s. 519-522; A. Taulé, Los cantos en el Misal Romano, „Phase” 165-166 (1988), s. 226-232; P. Tena, El canto y la música liturgica. Situación y perspectiva, „Phase” 182 (1991), s. 95-110.

${ }^{3}$ Kodeks Prawa Kanonicznego, kan. $230 \S 2$.

${ }^{4}$ Tamże, kan. 1173.

${ }^{5}$ Pius X, motu proprio Tra le sollecitudini, 22 XI 1903.
} 
artykule zostaną przedstawione ważniejsze dokumenty, począwszy od Soboru Watykańskiego II, czyli konstytucja o liturgii Sacrosanctum concilium, instrukcja Musicam sacram oraz - uwzględniając kontekst polski - instrukcja Episkopatu Polski o muzyce liturgicznej z 8 lutego 1979 roku.

\section{ACTUOSA PARTICIPATIO WEDŁUG SOBORU WATYKAŃSKIEGO II}

Aktualnym dokumentem, który reguluje muzykę i śpiew w Kościele rzymskokatolickim, jest konstytucja soborowa Sacrosanctum concilium, a konkretnie rozdział VI. Dokument podkreśla, że tradycja muzyczna Kościoła stanowi skarbiec o nieocenionej wartości, wybijający się ponad inne sztuki, przede wszystkim przez to, że śpiew kościelny związany ze słowami jest nieodzowną oraz integralną częścią uroczystej liturgii. Muzyka kościelna jest tym świętsza, im ściślej zwiąże się z czynnością liturgiczną. Sobór, zachowując zasady i przepisy kościelnej tradycji i karności oraz biorąc pod uwagę cel muzyki kościelnej, którym jest chwała Boża i uświęcenie wiernych, podaje pewne wytyczne w tym względzie.

- Czynność liturgiczna przybiera godniejszą postać, gdy służba Boża odbywa się uroczyście za śpiewem, przy udziale asysty i z czynnym uczestnictwem wiernych ${ }^{6}$.

- Należy starannie popierać zespoły śpiewacze, zwłaszcza przy kościołach katedralnych. Biskupi oraz inni duszpasterze powinni dbać o to, aby w każdej śpiewanej czynności liturgicznej wszyscy wierni umieli czynnie uczestniczyć w sposób im właściwy?

- Należy przywiązywać dużą wagę do teoretycznego i praktycznego wykształcenia muzycznego w seminariach, nowicjatach oraz domach studiów zakonników i zakonnic, a także w innych instytucjach i szkołach katolickich. Aby to wykształcenie zapewnić, należy starannie przygotować nauczycieli muzyki. Zaleca się także zakładanie wyższych instytutów muzyki kościelnej. Muzycy zaś i śpiewacy, a zwłaszcza chłopcy, powinni także otrzymać rzetelne wykształcenie liturgiczne ${ }^{8}$.

- Śpiew gregoriański Kościół uznaje za własny śpiew liturgii rzymskiej. Dlatego w czynnościach liturgicznych powinien on zajmować pierwsze miejsce wśród innych równorzędnych rodzajów śpiewu. Nie wyklucza się ze służby Bożej innych rodzajów muzyki kościelnej, zwłaszcza polifonii, byleby odpowiadały duchowi czynności liturgicznej9 .

\footnotetext{
${ }^{6}$ Sobór Watykański II, konst. Sacrosanctum Concilium, 113.

${ }^{7}$ Tamże, 114.

${ }^{8}$ Tamże, 115.

${ }^{9}$ Tamże, 116.
} 
- Należy troskliwie pielęgnować religijny śpiew ludowy, tak aby głosy wiernych mogły rozbrzmiewać podczas nabożeństw, a nawet w czasie czynności liturgicznych, stosownie do zasad i przepisów rubryk ${ }^{10}$.

- Ponieważ w niektórych krajach, zwłaszcza na misjach, żyją ludy posiadające własną tradycję muzyczną, która ma doniosłe znaczenie dla ich życia religijnego i społecznego, należy odnieść się do tej muzyki z szacunkiem i przyznać jej odpowiednie miejsce w kształtowaniu zmysłu religijnego tych ludów oraz w dostosowaniu kultu do ich charakteru. Przy muzycznym kształceniu misjonarzy trzeba pilnie troszczyć się o to, aby w miarę możności umieli pielęgnować tradycyjną muzykę tych ludów tak w szkołach, jak i w liturgii ${ }^{11}$.

- W Kościele łacińskim należy mieć w wielkim poszanowaniu organy piszczałkowe jako tradycyjny instrument muzyczny, którego brzmienie dodaje ceremoniom kościelnym majestatu. Inne natomiast instrumenty można dopuścić do kultu Bożego według uznania i za zgodą kompetentnej władzy terytorialnej, jeżeli nadają się albo mogą być przystosowane do użytku sakralnego, jeżeli odpowiadają godności świątyni i rzeczywiście przyczyniają się do zbudowania wiernych ${ }^{12}$.

- Muzycy przejęci duchem chrześcijańskim powinni tworzyć melodie, które posiadałyby cechy prawdziwej muzyki kościelnej i nadawały się nie tylko dla większych zespołów śpiewaczych, lecz także dla mniejszych chórów i przyczyniałyby się do czynnego uczestnictwa całego zgromadzenia wiernych. Przeznaczone do śpiewów kościelnych teksty powinny się zgadzać z nauką katolicką i winny być czerpane przede wszystkim z Pisma Świętego i źródeł liturgicznych ${ }^{13}$.

\section{INSTRUKCJA ŚWIĘTEJ KONGREGACJI OBRZĘDÓW MUSICAM SACRAM}

Dokument Musicam sacram można traktować jako interpretację konstytucji soborowej Sacrosanctum concilium (rozdział VI). Mówiąc o muzyce sakralnej, dokument rozumie pod tym pojęciem: śpiew gregoriański, polifonię sakralną dawną i współczesną w różnorakich jej formach, muzykę organową i przeznaczoną dla innych instrumentów dopuszczonych do użytku w kościele oraz sakralny śpiew ludowy - czy to liturgiczny, czy w ogóle religijny. W części ogólnej dokument zaleca, by duszpasterze zachęcali do śpiewu podczas sprawowania czynności liturgicznych ${ }^{14}$.

10 Tamże, 118

11 Tamże, 119

12 Tamże, 120.

13 Tamże, 121.

14 „Czynność liturgiczna przybiera postać bardziej dostojną, gdy jest połączona ze śpiewem; biorą w niej udział duchowni różnych stopni, wykonując przypadające im funkcje, i lud czynnie w niej uczestniczy. Dzięki takiej postaci modlitwa nabiera szczególnego namaszczenia, tajemnica 
Istota liturgicznego nabożeństwa wymaga, ażeby - prócz właściwego podziału funkcji i wykonania - każdy pełniący swoje zadania - czy to duchowny, czy świecki - spełniał tylko to, co do niego należy z natury rzeczy i na mocy przepisów liturgicznych, nadto - by znaczenie i charakter każdej części i każdego śpiewu były należycie podkreślone i zachowane. W tym celu jest rzeczą konieczną, by części przeznaczone $\mathrm{z}$ założenia do śpiewu były rzeczywiście śpiewane, i to z uwzględnieniem rodzaju i formy, jakie im odpowiadają ${ }^{15}$.

Dokument zwraca uwagę na bardzo ważną sprawę, a mianowicie że podniosłość liturgicznej czynności zależy nie tyle od bardziej ozdobnej formy muzycznej czy wspaniałości ceremonii, ile raczej od godnego i pobożnego odprawiania, od zachowania integralności samej czynności liturgicznej, czyli wykonania wszystkich jej części zgodnie z ich właściwym charakterem. Bogatsza oprawa muzyczna i większa wystawność ceremonii są niekiedy pożądane, gdy istnieje możliwość należytego ich wykonania. Sprzeciwiałoby się to jednak prawdziwie uroczystemu charakterowi nabożeństwa, gdyby zewnętrzny przepych powodował opuszczenie jakiegoś elementu, nadawał mu inne znaczenie lub prowadził do niewłaściwego wykonania ${ }^{16}$.

W drugiej części instrukcja zajmuje się osobami biorącymi udział w liturgii. Kapłan, zastępując osobę Chrystusa, przewodniczy zgromadzonej społeczności. Jego modlitw, które sam śpiewa lub odmawia głośno, wszyscy powinni słuchać pobożnie, ponieważ zanosi je w imieniu całego świętego ludu i wszystkich obecnych ${ }^{17}$.

Wierni spełniają swoją funkcję liturgiczną przez pełny, świadomy i czynny udział, czego domaga się sama natura liturgii i do czego lud chrześcijański na mocy chrztu świętego ma prawo i obowiązek. To zaś uczestnictwo:

- powinno przede wszystkim być wewnętrzne przez to, że wierni jednoczą swoje myśli z tym, co wypowiadają lub słyszą, i że współpracują z łaską Bożą,

- powinno być również zewnętrzne, to jest takie, które poprzez gesty, postawę ciała, wezwania, odpowiedzi i śpiew daje wyraz temu, co wierni wewnętrznie przeżywają ${ }^{18}$.

W dalszej kolejności instrukcja podaje wskazówki, w jaki sposób doprowadzić wiernych do czynnego udziału w śpiewie podczas liturgii:

świętej liturgii, oraz jej charakter hierarchiczny i społeczny lepiej się uwydatniają; dzięki zjednoczeniu w śpiewie pogłębia się jedność serc, okazałość świętych obrzędów ułatwia wznoszenie myśli ku niebu, a całość odprawianych obrzędów jest obrazem i zapowiedzią tego, co dokonuje się w świętym mieście Jeruzalem. Dlatego też duszpasterze powinni usilnie starać się wprowadzać odprawianie obrzędów świętych w takiej właśnie formie. Owszem, dobrze oni postępują, jeżeli do liturgii, odprawianej bez śpiewu, ale z udziałem ludu, dostosują odpowiedni podział funkcji i części właściwych dla liturgii odprawianej ze śpiewem. Winni jednak pamiętać, by do poszczególnych czynności mieć odpowiednich ludzi i by udział wiernych był jak najbardziej czynny". Święta Kongregacja Obrzędów, Instrukcja o muzyce w świętej liturgii Musicam sacram, 5 III 1967, 5.

15 Tamże, 6.

${ }^{16}$ Por. tamże, 11.

17 Tamże, 14.

${ }^{18}$ Tamże, 15. 
- udział ten musi obejmować przede wszystkim aklamacje, odpowiedzi na pozdrowienia kapłana czy asysty i odpowiedzi w modlitwach litanijnych, prócz tego antyfony i psalmy, jak również wersety responsoryjne, hymny i kantyki;

- przez odpowiednie katechezy i ćwiczenia należy stopniowo wprowadzać lud do coraz szerszego, a zarazem pełnego uczestnictwa w tym, co do niego należy;

- niektóre jednak śpiewy, zwłaszcza wtedy, gdy wierni nie zostali jeszcze wystarczająco przygotowani lub jeśli są to melodie wielogłosowe, mogą być wykonane jedynie przez zespół śpiewaków, byleby lud nie był całkowicie wykluczony od udziału w śpiewie tych części, które jemu przypadają. Nie pochwala się zwyczaju wykonywania przez sam chór całego Proprium i całego Ordinarium z całkowitym wykluczeniem ludu od śpiewu ${ }^{19}$.

Mówiąc o osobach biorących udział w liturgii, należy zwrócić także uwagę na: chór kościelny, zespół instrumentalny i zespół śpiewaków (schola cantorum). W świetle zasad Soboru Watykańskiego II dotyczących odnowy liturgicznej zadanie tych grup nabrało większego znaczenia. Do nich bowiem należy poprawne, zgodne z różnymi rodzajami śpiewu wykonywanie właściwych im części liturgii oraz wspomaganie wiernych, gdy ci poprzez śpiew uczestniczą w liturgii. Stąd też powinny istnieć i być otaczane opieką chóry, kapele muzyczne i zespoły śpiewaków (schola cantorum) przy kościołach katedralnych, większych kościołach, w seminariach i zakonnych domach studiów. Wskazane także jest, aby podobne, choćby małe, chóry istniały również przy kościołach mniejszych. Kapele muzyczne istniejące przy bazylikach, katedrach, klasztorach i innych znaczniejszych kościołach, które zdobyły sławę, przechowując i rozwijając przez wieki kulturę muzyczną o bezcennej wprost wartości, powinny nadal istnieć w oparciu o własne, przekazane tradycją statuty, przejrzane i zatwierdzone przez ordynariusza miejsca. Dyrygenci tych zespołów, a także rządcy kościołów powinni zadbać o to, by lud zawsze włączał się w śpiew, wykonując przynajmniej łatwiejsze części do niego należące. Tam zaś, gdzie założenie nawet małego zespołu śpiewaków jest niemożliwe, należy się postarać przynajmniej o jednego lub dwóch kantorów, należycie przygotowanych, dla intonowania pieśni, a gdy lud śpiewa, dla przewodniczenia i podtrzymywania tego śpiewu. Zespół śpiewaków (schola cantorum), zależnie od przyjętych miejscowych zwyczajów i innych okoliczności może się składać albo z mężczyzn i chłopców, albo tylko z mężczyzn lub tylko chłopców, albo z mężczyzn i niewiast, a nawet, jeżeli nie można inaczej, tylko z niewiast ${ }^{20}$.

Trzecia część instrukcji dotyczy śpiewu podczas mszy świętej. Przy sprawowaniu Eucharystii z udziałem ludu, zwłaszcza w niedziele i święta, należy, o ile to możliwe, nawet kilka razy w tym samym dniu odprawiać mszę świętą śpiewaną. Jednakże jeśli chodzi o mszę świętą śpiewaną, z uwagi na duszpasterskie korzyści wprowadza się w zakresie śpiewu stopnie uczestnictwa, by stosownie do możliwości uczestniczącej

\footnotetext{
19 Tamże, 16

${ }^{20}$ Tamże, 19-22.
} 
grupy ułatwić celebrę uroczystej mszy świętej śpiewanej. Według instrukcji musi być jednak zachowany porządek wśród tych stopni, mianowicie: pierwszy stopień może być użyty nawet sam, drugi zaś i trzeci, tak w całości, jak i częściowo, nigdy bez pierwszego. I tak do pierwszego stopnia należą:

- w obrzędach wejścia: pozdrowienie kapłana z odpowiedzią ludu; modlitwa,

- w liturgii słowa: aklamacje przy Ewangelii,

- w liturgii eucharystycznej: modlitwa nad darami ofiarnymi; prefacja z dialogiem i Sanctus; doksologia kończąca kanon; modlitwa Pańska ze wstępem i embolizmem; Pax Domini; modlitwa po Komunii; formuły odesłania wiernych.

Do drugiego stopnia należą:

- Kyrie, Gloria i Agnus Dei,

- Symbol,

- modlitwa wiernych.

Do trzeciego stopnia należą:

- śpiew przy procesji wejścia i komunii,

- śpiew po lekcji,

- alleluja przed Ewangelią,

- śpiew na ofiarowanie,

- śpiew tekstów Pisma Świętego ${ }^{21}$.

Części stałe mszy świętej - ordinarium missae - jeśli się je wykonuje w układzie wielogłosowym, może śpiewać zespół według ustalonych już zasad, albo a capella, albo z towarzyszeniem instrumentów, jednakże ludu od śpiewu całkowicie wykluczać nie wolno. W innych wypadkach śpiewy części stałych mszy świętej można rozdzielić między zespół i lud. Można też wiernych podzielić na dwa chóry, które śpiewają albo na przemian pojedyncze wiersze tekstu albo, jeśli to bardziej wskazane, stosownie podzielone większe części całego tekstu. W tych wypadkach należy jednak pamiętać, że Credo - ponieważ jest wyznaniem wiary - powinni śpiewać wszyscy wspólnie lub przynajmniej w taki sposób, by cały lud miał w śpiewie stosowny udział, Sanctus - jako aklamacja kończąca prefację - wypada, by było odśpiewane przez wszystek lud razem z kapłanem, Agnus Dei można powtarzać tyle razy, ile zachodzi potrzeba, zwłaszcza we mszy koncelebrowanej w czasie łamania Hostii. Zaleca się, by lud brał udział w tym śpiewie, przynajmniej przez wezwanie końcowe ${ }^{22}$.

Instrukcja Musicam sacram zachęca, by modlitwę pańską wygłaszał lud wraz z kapłanem. Jeżeli śpiewa się ją w języku łacińskim, należy używać melodii będących dotąd prawnie w użyciu, jeżeli natomiast śpiewa się w języku ojczystym, melodie muszą być zatwierdzone przez odpowiednią władzę terytorialną̧ ${ }^{23}$.

Święta Kongregacja Obrzędów podkreśla, aby przywiązywać dużą wagę do teoretycznego i praktycznego wykształcenia muzycznego w seminariach, nowicjatach

\footnotetext{
${ }^{21}$ Tamże, 29-31.

${ }^{22}$ Tamże, 34.

${ }^{23}$ Tamże, 35.
} 
i domach studiów zakonów męskich i żeńskich oraz w innych instytucjach i szkołach katolickich, a zwłaszcza w wyższych instytutach do tego celu specjalnie przeznaczonych. Należy przede wszystkim dbać o studium i praktykę śpiewu gregoriańskiego, gdyż stanowi on ważną podstawę dla uprawiania muzyki sakralnejej.

Z kolei utwory tworzonej współcześnie muzyki sakralnej muszą być zgodne $\mathrm{z}$ wyłożonymi zasadami i przepisami. Muszą mianowicie mieć cechy prawdziwej muzyki kościelnej i nadawać się nie tylko dla większych zespołów śpiewaczych, lecz także dla mniejszych chórów i przyczyniać się do czynnego uczestnictwa całego zgromadzenia wiernych. Jeżeli zaś chodzi o dawną muzykę, to najpierw należy wykorzystać te utwory, które odpowiadają wymogom odnowionej liturgii. Następnie znawcy muzyki sakralnej dokładnie rozważą, czy nie można by także innych utworów dostosować do tych wymagań. Wreszcie utwory, których nie da się pogodzić z naturą lub z duszpasterskimi celami obrzędów liturgicznych, można z pożytkiem wykorzystać z okazji ćwiczeń pobożnych, zwłaszcza w nabożeństwach Słowa Bożego ${ }^{25}$.

Rozdział VIII instrukcji jest poświęcony instrumentalnej muzyce sakralnej. W tym temacie Kongregacja wyjaśnia, iż instrumenty muzyczne mogą być bardzo pożyteczne przy sprawowaniu świętych obrzędów czy to do akompaniamentu, czy do gry solowej. Podkreśla, że w Kościele łacińskim należy mieć w wielkim poszanowaniu organy piszczałkowe jako tradycyjny instrument muzyczny, którego brzmienie dodaje ceremoniom kościelnym majestatu, a umysły wiernych porywa do Boga i spraw niebieskich. Inne natomiast instrumenty można dopuścić do kultu Bożego według uznania i za zgodą kompetentnej władzy terytorialnej, jeżeli nadają się albo mogą być przystosowane do użytku sakralnego, jeżeli odpowiadają godności świątyni i rzeczywiście przyczyniają się do zbudowania wiernych. Przy dopuszczaniu i używaniu instrumentów muzycznych należy brać pod uwagę ducha i tradycję poszczególnych narodów. Jednakże to, co według ogólnego przekonania i faktycznego używania odpowiednie jest tylko dla muzyki świeckiej, należy bezwzględnie wyłączyć z wszelkich czynności liturgicznych i ćwiczeń pobożnych. Wszystkie zaś instrumenty muzyczne dopuszczone do kultu Bożego powinny być używane w ten sposób, by odpowiadały świętości obrzędów, dodawały blasku kultowi Bożemu i służyły zbudowaniu wiernych. Akompaniament na instrumentach muzycznych podtrzymuje śpiew, ułatwia udział w czynnościach liturgicznych i przyczynia się do głębszego zjednoczenia zgromadzonych wiernych. Nie powinien on jednak do tego stopnia zagłuszać śpiewu, by nie można było zrozumieć słów. Gdy zaś kapłan lub ktoś z asysty wymawia głośno wyznaczony dla siebie tekst, wówczas instrumenty milczą. Gra na organach czy innym uznanym instrumencie muzycznym dopuszczalna jest we mszy śpiewanej i czytanej jako akompaniament podczas śpiewu zespołu i ludu. Gra solowa możliwa jest jedynie na początku, zanim kapłan przyjdzie do ołtarza, na przygotowanie darów, podczas komunii i na końcu

${ }^{24}$ Tamże, 52.
${ }^{25}$ Tamże, 53. 
mszy świętej. Tej samej zasady, stosując ją analogicznie, można się trzymać przy innych nabożeństwach. Gry solowej na instrumentach nie dopuszcza się w okresie Adwentu, Wielkiego Postu, w czasie Triduum Paschalnego oraz w oficjum i we mszy świętej za zmarłych. Instrukcja zawiera postulat, by organiści oraz inni muzycy nie tylko umieli biegle grać na powierzonym instrumencie, ale posiadali także znajomość ducha świętej liturgii i wnikali weń coraz głębiej, by spełniając swój urząd choćby tylko czasowo, uświetniali obrzęd, zgodnie z naturą poszczególnych jego części, i ułatwiali wiernym udział w liturgicznej czynności ${ }^{26}$.

\section{INSTRUKCJA EPISKOPATU POLSKI $O M U Z Y C E$ LITURGICZNEJ PO SOBORZE WATYKAŃSKIM II}

Instrukcja Episkopatu Polski o muzyce liturgicznej z 8 lutego 1979 roku ma charakter normatywny. Można powiedzieć, że stanowi ona swoisty pas transmisyjny, który przenosi na realia Polski instrukcję Musicam sacram. Dokument podkreśla, że muzyka, a zwłaszcza śpiew, jest nie tylko ozdobą liturgii, ale jest jej integralną częścią, dlatego należy zabiegać, by w miarę możliwości były one odprawiane ze śpiewem. Spiew „sprzyja zjednoczeniu zgromadzonych i otwiera ich dusze na tajemnice roku liturgicznego"27.

Przy sprawowaniu Eucharystii z udziałem wiernych, zwłaszcza w niedziele i święta, należy nawet kilka razy w tym samym dniu odprawić mszę świętą ze śpiewem $^{28}$. Dobierając części, które mają być śpiewane, pierwszeństwo należy przyznać tym, które śpiewa kapłan i asystujący, a lud na nie odpowiada, oraz wykonywanym wspólnie przez kapłana i lud ${ }^{29}$. Instrukcja podkreśla, że śpiewu stałych części mszy świętej, a także psalmu responsoryjnego i śpiewu przed Ewangelią, które stanowią integralną część liturgii słowa, nie wolno zastępować pieśniami nawet mającymi imprimatur władzy kościelnej ${ }^{30}$. Śpiew gregoriański powinien zajmować pierwsze miejsce wśród innych równorzędnych rodzajów śpiewu. Dlatego też wierni powinni umieć śpiewać po łacinie niektóre części mszy świętej ${ }^{31}$.

Biskupi w instrukcji podkreślają, że podczas liturgii nie wolno wykonywać muzyki mającej charakter wyraźnie świecki np. jazzu, big beatu itp. Muzyka ta, „niezgodna $z$ duchem i powagą liturgii, nie sprzyja jej refleksyjnemu przeżywaniu, a ponadto często wyłącza całe zgromadzenie wiernych od udziału w śpiewie.

${ }^{26}$ Tamże, 62-67.

${ }^{27}$ Kongregacja Kultu Bożego, Ogólne wprowadzenie do Mszału rzymskiego, 25.

${ }^{28}$ Konferencja Episkopatu Polski, Instrukcja O muzyce liturgicznej po Soborze Watykańskim II (dalej: Instrukcja o muzyce liturgicznej), 8 II 1979, 11, w: Dokumenty Duszpastersko-Liturgiczne Episkopatu Polski 1966-1993, Lublin 1994, s. 287-298.

${ }^{29}$ Por. Kongregacja Kultu Bożego, Ogólne wprowadzenie do Mszału rzymskiego, 19.

${ }^{30}$ Konferencja Episkopatu Polski, Instrukcja o muzyce liturgicznej po Soborze Watykańskim II, 13.

31 Tamże, 17. 
Poza liturgią można urządzać specjalne nabożeństwa gromadzące młodych ludzi uprawiających ten rodzaj muzyki. Duszpasterze mają obowiązek tak kierować tymi nabożeństwami, by miały one charakter religijny i by zawsze płynęło z nich dobro duchowe uczestników"32.

Instrukcja wypowiada się na temat instrumentów muzycznych. Zauważa, że w Kościele łacińskim należy mieć w poszanowaniu organy piszczałkowe jako tradycyjny instrument muzyczny. Organy powinny znajdować się we wszystkich kościołach w Polsce. Tzw. organy elektronowe dopuszcza się do użytku jako instrument tymczasowy. Poza organami wolno używać w liturgii innych instrumentów z wyjątkiem tych, które są zbyt hałaśliwe lub wprost przeznaczone do wykonywania współczesnej muzyki rozrywkowej. Wyłącza się z użytku liturgicznego, zgodnie z tradycją, takie instrumenty, jak: fortepian, akordeon, mandolina, gitara elektryczna, perkusja, wibrafon itd. Ponadto muzyka wykonywana podczas czynności liturgicznej winna być wykonywana „na żywo”, dlatego nie wolno zastępować śpiewu zgromadzonych lub gry na instrumentach muzyką odtwarzaną ${ }^{33}$.

W końcowych dyspozycjach instrukcja podejmuje zagadnienie wychowania muzycznego. Aby uzyskać takie wychowanie muzyczne duchowieństwa, należy:

- w seminariach duchownych diecezjalnych i zakonnych wprowadzić program nauczania muzyki kościelnej;

- dokształcać w tej dziedzinie kapłanów już pracujących w duszpasterstwie;

- zatroszczyć się o odpowiednie nauczanie muzyki kościelnej w nowicjatach zakonnych męskich i żeńskich;

- zatroszczyć się w szczególny sposób, by chorał gregoriański znalazł więcej miejsca w liturgii seminariów duchownych, podczas rekolekcji i zjazdów duchowieństwa, w kościołach katedralnych ${ }^{34}$.

Instrukcja podejmuje problemy szczegółowe, natomiast inne przypadki, w tym także sprawy trudniejsze, należy przedkładać do rozstrzygnięcia Diecezjalnej Komisji Muzyki Kościelnej lub Podkomisji ds. Muzyki Kościelnej przy Komisji Episkopatu Polski ds. Liturgii.

Przedstawione wyżej trzy dokumenty stanowią podstawę prawną w kwestii muzyki i śpiewu po Soborze Watykańskim II w Polsce. Później pojawiały się przemówienia papieskie, referaty na kongresach międzynarodowych, instrukcje biskupów wielu

\footnotetext{
32 Tamże, 20.

33 Tamże, 28-30.

${ }^{34}$ Tamże, 31.
} 
krajów, jednak wszystkie te teksty ${ }^{35}$ odnoszą się do dyspozycji prawnych zawartych w konstytucji Sacrosanctum concilium i instrukcji Musicam sacram.

Jan Paweł II zachęcał do dbania o wysoki poziom tekstów i melodii muzyki sakralnej. Stwierdził: ,trzeba starannie przygotować wspólny śpiew, ponieważ jest to szczególnie stosowny wyraz radości serca, który podkreśla uroczysty charakter zgromadzenia i sprzyja dzieleniu się jedną wiarą i miłością. Należy zatem zadbać o wysoką jakość zarówno tekstów, jak i melodii, aby pojawiające się dziś nowe i twórcze propozycje były zgodne z przepisami liturgicznymi oraz godne kościelnej tradycji, która w sferze muzyki sakralnej może się poszczycić dorobkiem o nieocenionej wartości”36.

\section{SŁOWA KLUCZOWE}

instrukcja Musicam sacram, konstytucja Sacrosanctum concilium, muzyka sakralna, śpiew liturgiczny

\section{SUMMARY}

\section{Legal requirements regulating liturgical music and singing after the Second Vatican Co- uncil (Polish background)}

The article addresses the issue if legal requirements regulating liturgical music and singing. There is no mention of it in The Code of Canon Law of 1983. However, the last one hundred and fifty years were characterised in this respect by two great reforms. The first one of 1903 was conducted by Pope Pius X, and the second one was done by means of the Second Vatican Council. The main subject of the first reform was the recovery of the ,purity” of music in response to numerous instances of abuse which polluted liturgical music. The second reform was aimed at active and conscious participation of the faithful during a liturgical assembly. This paper presents the most important documents regarding this subject after the Second Vatican Council, including the Constitution of the Sacred Liturgy (Sacrosanctum concilium), Musicam sacram instruction and - with regard to the Polish background - Polish Episcopate instruction of 8 February 1979 on liturgical music.

\section{KEYWORDS}

Musicam sacram instruction, Sacrosanctum concilium constitution, sacred music, liturgical singing

${ }^{35}$ Paweł VI, Muzyka i śpiew w stużbie kultu Bożego. Przemówienie do Stowarzyszenia św. Cecylii (1968); Jan Paweł II, Muzyka i liturgia. Przemówienie podczas Międzynarodowego Kongresu Muzyki Sakralnej (1980); Konferencja Biskupów USA, Muzyka w kulcie katolickim (1983); Konferencja Biskupów Portugalii, Nota duszpasterska na temat śpiewu liturgicznego (1985); Konferencja Biskupów Hiszpanii, Śpiewy podczas Eucharystii (1987). Powyższe teksty można porównać w: La musica en la liturgia. Documentos, Barcelona 1994.

${ }^{36}$ Jan Paweł II, list apost. Dies Domini, 50. 